\title{
Late dissemination of ependymoma: case report
}

\author{
G. Bademci; K. Tun*; E. Erden**; C. Evliyaoglu and A. Unlu***
}

Department of Neurosurgery. University of Kirikkale. Faculty of Medicine. Kirikkale. Turkey. *Neurosurgery Division. Ankara Numune Hospital. Ankara. Turkey. **Department of Pathology and ***Neurosurgery. Ankara University. School of Medicine. Ankara. Turkey.

\section{Summary}

Spinal cord dissemination over 10 years after surgical removal of the fourth ventricle ependymoma without local recurrence is extremely rare. A 49 -year-old male underwent a macroscopically gross total removal of the fourth ventricle ependymoma and postoperative radiothe rapy to the posterior fossa. Twelve years after the initial operation, the patient complained from uncontrolled fever attacks, low back pain and numbness of the legs. Spinal Magnetic Resonance Imaging revealed intradural extramedullary mass lesions located at the thoracic 2-3 and lumbar 5 vertebrae levels. Cerebrospinal fluid exami nation showed no tumour cells. He underwent total excision of these spinal lesions. Although the majority of the recurrences take place within a few years after surgery, we experienced a case with multiple spinal disseminations 12 years after the resection of the fourth ventricle ependymoma and administration of the radiation therapy to the posterior fossa. Up to our knowledge, this case represents the second unusual late recurrence reported in the literature. We conclude that low grade ependymomas should be followed neurologically and radiologically for more than 10 years after the initial treatment.

KEY WORDS: Ependymoma. Dissemination. Spinal cord.

Diseminación tardía de un ependimoma. Caso clínico

\section{Resumen}

La diseminación raquídea, después de la extirpación quirúrgica de un ependimoma del cuarto ventrículo, sin recurrencia local, es muy rara. Un varón de 49 años fue intervenido de un ependimoma del IV ventrículo, con resección total y radioterapia postoperatoria de la fosa posterior. Doce años después de esta intervención, el paciente comenzó a quejarse de episodios febriles incontrolables, dolor lumbar y adormecimiento en las piernas.

Recibido;22-08-06. Aceptado: 12-12-06
La resonancia magnética mostraba lesiones localizadas a la altura de la 2-3 ${ }^{\mathrm{a}}$ vértebra dorsal y de la L5. El líquido cefalorraquídeo no mostraba células tumorales. Fue operado de ambos tumores raquídeos, con resección total.

Aunque la mayoría de las recurrencias tienen lugar en los primeros años después de la operación, hemos observado un caso con diseminación raquídea múltiple, después de la resección de un ependimoma del IV ventrículo y radioterapia de la fosa posterior. Que sepamos, este caso es el segundo de recurrencia tardía, publicado en la literatura. En conclusión, los ependimomas de bajo grado deben ser vigilados neurológica y radiológicamente durante más de diez años después del tratamiento inicial.

PALABRAS CLAVE: Ependimoma. Diseminación. Médula espinal.

Introduction

Intracranial ependymomas constitute approximately $3-5 \%$ of all intracranial tumours ${ }^{6,7}$. Prognostic factors such as the extent of tumour resection, age of the patient, tumour location, histological composition and the role of the adjuvant therapies still remain controversial ${ }^{4,10,16}$. Intracranial ependymomas may spread by local infiltration in the surrounding brain or by dissemination through the cerebrospinal fluid (CSF). The true incidence of cerebrospinal dissemination of ependymomas is still unknown. It is commonly known that especially high grade ependymomas tend to disseminate few years after the initial diagnosis ${ }^{13}$. Late recurrence of low grade ependymomas is not unknown, but unusual ${ }^{2,8,11,12}$. We experienced a case with multiple spinal cord disseminations, 12 years after total removal of the fourth ventricle low grade ependymoma without a local failure. This case report emphasizes that prolonged neurological and imaging review is reasonable. Furthermore, as a matter of fact that long dormant period may be considered as one of ependymoma's

Abreviaturas. CSF: cerebrospinal fluid. CT: cranial tomography. MRI: magnetic resonance imaging. RT: radiation therapy. 
behavioural dynamics.

\section{Case report}

A 49-year-old male was admitted to the department of neurosurgery, Ankara University, School of Medicine in 1988 with a mass lesion located in the posterior fossa. A gross total removal of the $4^{\text {th }}$ ventricle ependymoma via median suboccipital craniotomy had been performed. CSF cytology was negative on the onset of the disease. The tumour was diagnosed as Grade II ependymoma (Fig 1). The patient was discharged with minimal truncal ataxia and lateral gaze nistagmus. He underwent 45 Gy of radiation therapy (RT) to the posterior fossa 3 months after the surgical intervention. Cranial tomography (CT) and/or magnetic resonance imaging (MRI) had been repeated every 6 months for the first two years and then yearly. Radiologic findings revealed no residue or recurrence in primary tumour site (Fig 2). The history of the patient was unremarkable except an excisional biopsy for the basal cell carcinoma of the anus six years ago. The patient had a normal life for the following years, till he complained from uncontrolled fever attacks started in June 2000. At that time he complained back and low back pain and numbness of the legs. While the patient was examined in infectious disease clinic for the etiology of unidentified fever and high sedimentation degrees, he was consultated to the neurosurgery department. CSF cytology was negative. Spinal MRI showed intradural extramedullary mass lesions located at the levels of thoracic 2-3 (Fig 3a) and lumbar 5 (Fig 4a). Total laminectomy for thoracic 2-3-4 and lumbar 5 vertebrae and total excision of the intradural extramedullary tumours were performed (Fig $3 b$ and Fig 4b). Pathological diagnosis of the spinal tumours revealed Grade II ependymoma (Fig 5).

\section{Discussion}

Proliferation and dissemination kinetics of ependymomas still remain unpredictable. Previously reported extremely rare events emphasized that ependymomas should be followed for a long-term period ${ }^{2,8}$. But the frequency and extent of radiologic follow-up is still controversial. Celli et al reported a late recurrence of filum terminale ependymoma as long as 42 years after the total removal ${ }^{2}$. Nakasu et al reported a case of fourth ventricle ependymoma disseminated 13 years after the resection without a local failure ${ }^{8}$. Plans et al reported an intracranial retrograde dissemination in filum terminale myxopapillary ependymoma three years after the initial diagnosis ${ }^{11}$. Rehman et al reported an intracranial ependymoma case recurred 10 years after completing chemotherapy ${ }^{12}$. Present case is the second delayed dissemination of intracranial ependymoma without local

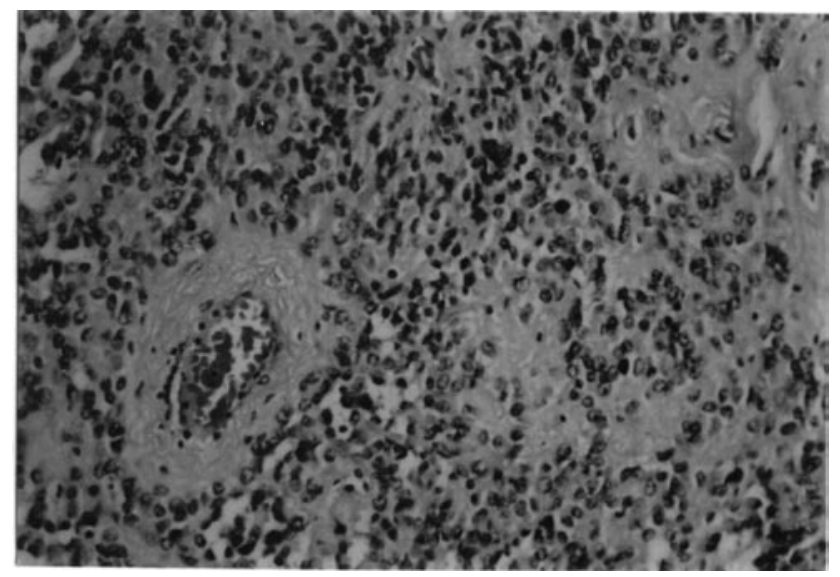

Figure 1. Moderately cellular glioma with monomorphic nuclear morphology and perivascular pseudorosettes, $\mathrm{H}$ Ex200.

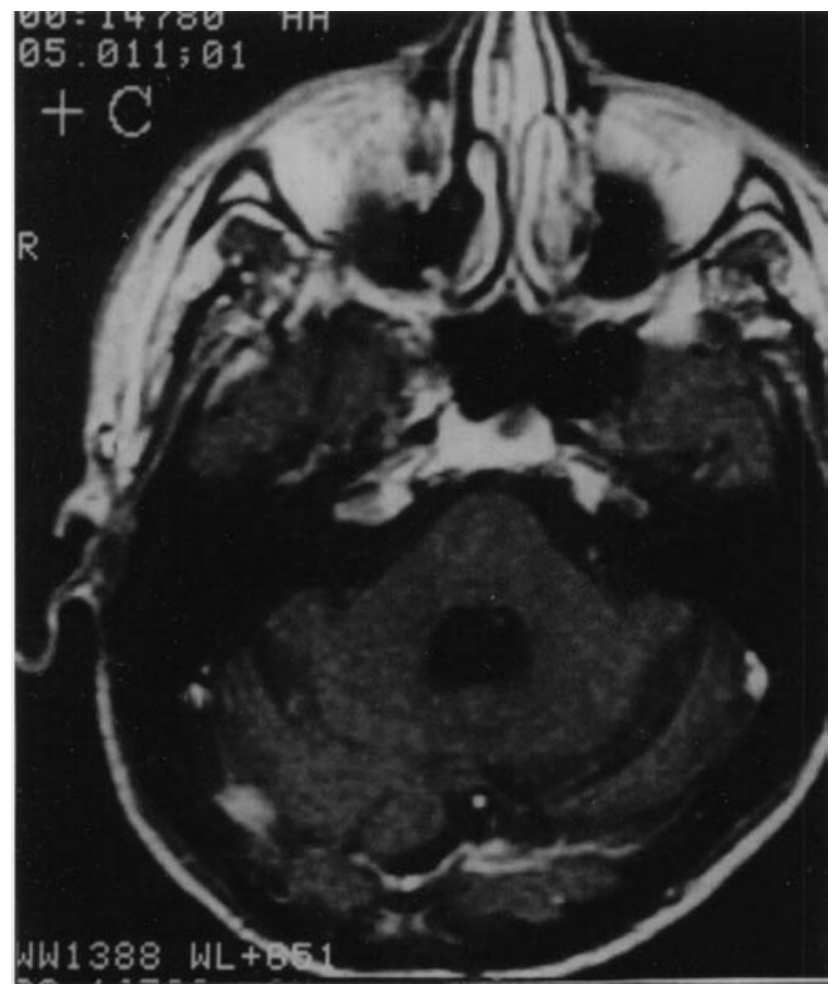

Figure 2. Gadolinium -enhanced T1- weighted postoperative image showing no residue or recurrence but postoperative changes in the posterior fossa.

recurrence 12 years after the initial therapy. In fact, the true incidence may be higher, because spinal radiological follow-up is commonly neglected after local control of the primary tumor.

As ependymomas are derived from the ependymal and subependymal cells lining the cerebral ventricles and the central canal of the spinal cord, potential dissemination 


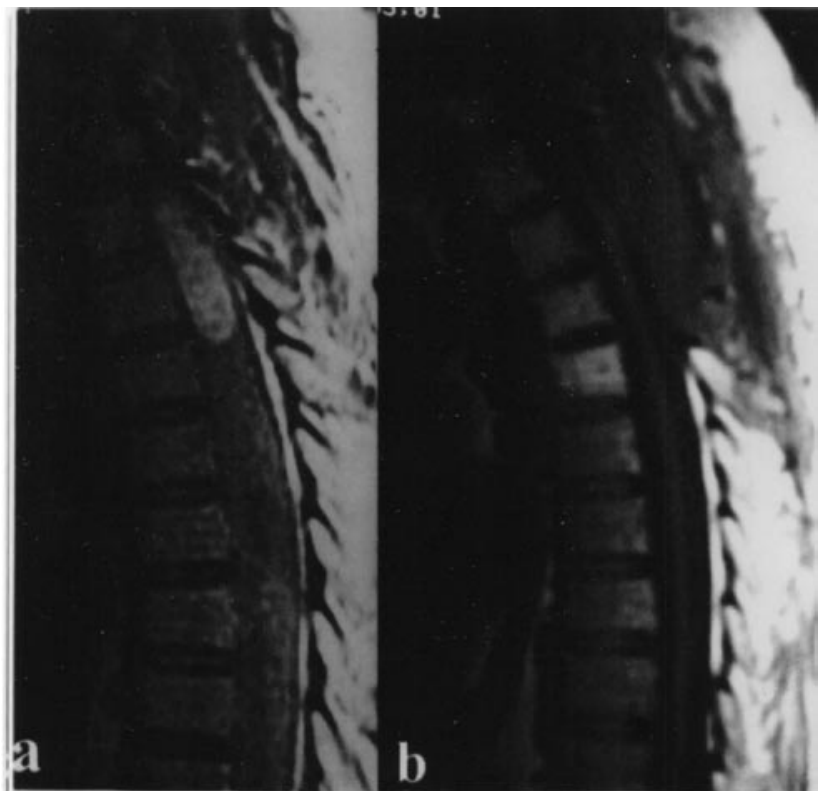

Figure 3. a: Gadolinium -enhanced T1-weighted sagittal image showing thoracic 2-3 well-defined mass lesion in the spinal canal; $b$ : Gadolinium -enhanced T1- weighted postoperative image indicating total excision of the mass lesion in the spinal canal.

of the cranial ependymoma through CSF or leptomeningeal pathways should be considered carefully. The true frequency of this spreading is unknown. The incidence of seeding is accepted $8.7 \%$ for high grade compared to $5 \%$ for low grade ${ }^{14}$. Exfoliated tumour cells are carried by the flow of CSF to other parts of the neuroaxis, especially to the basal cisterns and cauda equina, where tumour cells tend to settle as a result of gravity and slow CSF flow. The dissemination of malignant tumour cells depends on their replication and ability to adhere to the matrix of a biological barrier, such as basement membrane, to degrade the matrix, and to migrate through this more permeable barrier. Although most cases of dissemination become symptomatic within five years concomitantly with local recurrences, a few cases disseminated later ${ }^{8}$. Possible reasons for delayed dissemination may be related to ependymoma dynamics itself or postoperative radiotherapy administration. Ependymomas still keep their behavioural mystery. Present case indicated that there may be a so-called "sleeping period" in ependymoma dissemination or metastasis. Another possibility may be addressed that the patients with ependymoma may have an intrinsic (perhaps genetic) predisposition to develop ependymomas and that this late recurrence is in fact a second tumour rather than a dissemination.

RT is considered as a part of whole ependymoma treatment ${ }^{15}$. The goal of RT is to eradicate clonogenic tumour cells within the CSF thereby preventing subarachnoid metastases and possible re-seeding of tumour

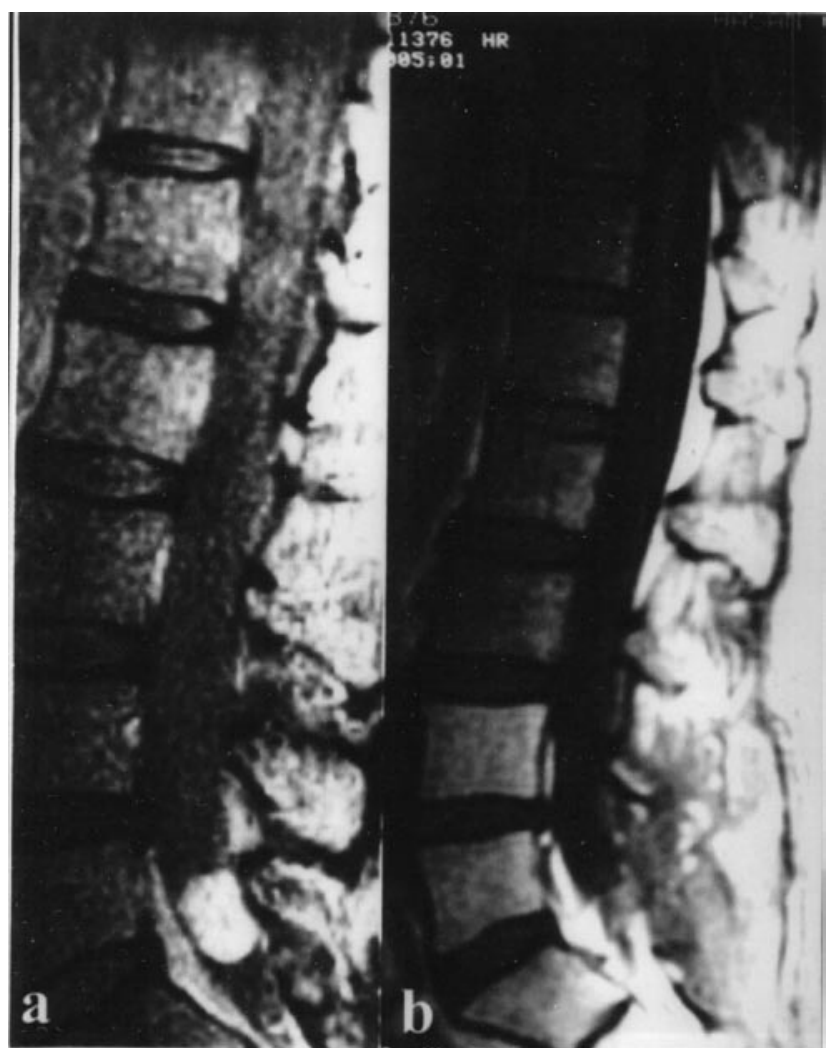

Figure 4. a: Gadolinium -enhanced T1-weighted sagittal image showing lumbar 5 well-defined mass lesion in the spinal canal; b: Gadolinium -enhanced T1- weighted postoperative image indicating total excision of the mass lesion in the spinal canal.

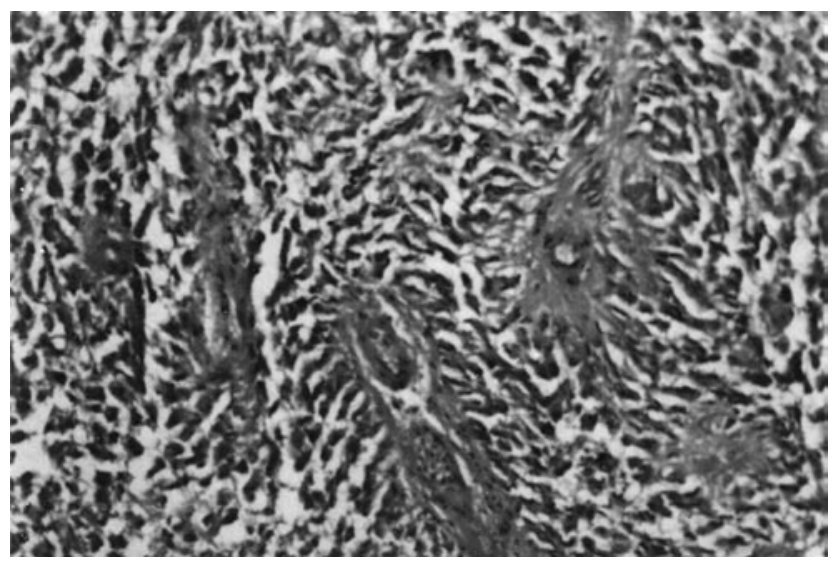

Figure 5: Moderately cellular glioma with elongated tumour cells radially arranged around vessels, $H$-Ex200

locus $^{16}$. Vanuytsel et al. indicated that there is no statistical difference in survival in low grade tumours when patients are irradiated indicated to whole brain or local field, with or without spinal irradiation while it was important for the high grade tumors ${ }^{16}$. Paulino et al. suggested local field RT regardless of grade or location, with the exception of patients 
who present with neuroaxis spread at initial diagnosis ${ }^{10}$. On the present evidence spinal metastases are not prevented by prophlactic spinal irradiation, regardless of tumor grade and site $^{17}$. Kawabata et al. suggested that postoperative radiation should be focused on local control, especially for Grade II ependymomas instead of prophylactic spinal radiation $^{5}$. The pooled data show that the use of spinal irradiation does not seem to improve treatment results and eliminate the risk of recurrence $\mathrm{e}^{5,9,10,17,18}$.

Delayed metastasis or late second tumour development may be accepted as one of the main characteristics of ependymoma if the reported cases increase. There is still not much data about ependymoma kinetics and the factors affecting and triggering the dissemination even local control is achieved. But it is certain that early detection of dissemination during the asymptomatic stage may prolong survival ${ }^{1,3}$ and the patients with benign ependymoma should be followed longer than those with anaplastic ones. We also concluded that long term follow-up (not less than 10 years) is recommended because of the tendency in these tumours toward late recurrences despite radical removal and postoperative RT administration.

\section{References}

1. Branger, D.F., Civatte, M., Labit, CB., Gouvernet, J., Gambarelli, D., Gentet, JC., Lena, G., Choux, M., Pellissier, JF.: Prognostic factors in intracranial ependymomas in children. J Neurosurg 2000; 93: 605-613.

2. Celli, P., Cervoni, L., Salvati, M., Cantore, G.: Recurrence from filum terminale ependymoma 42 years after total removal and radiotherapy. J Neuro-Oncol 1997; 34: 153-156.

3. Good, C.D., Wade, A.M., Hayward, R.D., Phipps, K.P., Michalski, A.J., Harkness, W.F.J., Chong, W.K.: Surveillance neuroimaging in childhood intracranial ependymoma: how effective, how often, and for how long? J Neurosurg 2001; 94 : 27-32.

4. Grabenbauer, G.G., Barta, B., Erhardt, J., Buchfelder, M., Thierauf, P., Beck, J.D., Sauer, R.: Prognostische faktoren und ergebnisse nach kombiniert operativer und strahlentherapeutischer behandlung des ependymoms. Strahlenther Onkol 1992; 168: 679-685.

5. Kawabata,Y., Takahashi, J.A., Arakawa, Y., Hashimoto, N.: Long-term outcome in patients harboring intracranial ependymoma. J Neurosurg 2005; 103: 31-37.

6. Kleihues, P., Burger, P.C., Scheithauer, B.W.: Histological typing of tumors of the central nervous system: World Health Organization international classification of tumors. Berlin: Springer 1993.
7. Korshunov, A., Golanov, A., Timirgaz, V.: Immunohistochemical markers for intracranial ependymoma recurrence. Analysis of 88 cases. J Neurol Sci 2000; 177: 72-82.

8. Nakasu, S., Ohashi, M., Suzuki, F., Matsuda, M.: Late dissemination of fourth ventricle ependymoma: a case report. J Neuro-Oncol 2001; 55: 117-120.

9. Oya, N., Shibamoto, Y., Nagata, Y., Negore, Y., Hiraoka, M.: Postoperative radiotherapy for intrakranial ependymoma: analysis of prognostic factors and paterns of failure. J Neuoroncol 2002; 56: 87-94.

10. Paulino, A., Wen, B.C., Buatti, J., Hussey, D., Zhen, W.K., Mayr, N., Menezes, A.: Intracranial ependymomas. Am J Clin Oncol (CCT) 2002; 25: 117-122.

11. Plans, G., Brell, M., Cabiol, J., Villa, S., Torres, A., Acebes, J.J.: Intracranial retrograde dissemination in filum terminale myxopapillary ependymomas. Acta Neurochir (Wien) 2006; 148: 343-346.

12. Rehman, S., Brock, C., Newlands, E.S.: A case report of a recurrent intracranial ependymoma treated with temozolamide in remission 10 years after completing chemotherapy. Am J Clin Oncol (US) 2006; 29: 106-107.

13. Salazar, O., Castro-Vita, H., VanHoutte, P., Rubin, P., Aygun, C.: Improved survival in cases of intracranial ependymoma after radiation therapy. J Neurosurg 1983; 59: 652-659.

14. Schiffer, D.: Neuropathology and imaging The ways in which glioma spreads and varies in its histological aspects. Boston, MA: Martines Nishoff 1986; pp163-172.

15. Shaw, E., Evans, R., Scheithauer, B.W., Ilstrup, D., Earle, J.D.: Postoperative radiotherapy of intracranial ependymoma in pediatric and adult patients. . Int J Radiation Oncol Biol Phys 1987; 13: 1457-1462.

16. Vanuytsel, L.J., Bessell, E., Ashley, S., Bloom, J.G., Brada, M.: Intracranial ependymoma: Long term results of a policy of surgery and radiotherapy. Int J Radiation Oncol Biol Phys 1991; 23: 313-319.

17. Vanuytsel, L., Brada, M.: The role of prophylactic spinal irradiation in localized intracranial ependymoma. Int $\mathrm{J}$ Radiat Oncol Biol Phys 1991; 21: 825-830.

18. Wallner, K.E., Wara, W., Sheline, G.E., Davis, R.: Intracranial ependymomas: Results of treatment with partial or whole brain irradiation without spinal irradiation. Int J Radiation Oncol Biol Phys 1986; 12: 1937-1941.

Bademci, G.; Tun, K.; Erden, E.; Evliyaoglu, C.; Unlu, A.: Late dissemination of ependymoma: case report. Neurocirugía 2007; 18: 333-336.

Address: Gulsah Bademci, M.D. Buketkent Mah. Iller Sitesi 9. Blok No: 9. 06530 Cayyolu/ Ankara/Turkey 